\title{
O envio dos carmelitas à América portuguesa em 1580: a carta de Frei João Cayado como diretriz de atuação
}

\author{
André Cabral Honor[1]
}

\begin{abstract}
Resumo
Iniciando com a narrativa das expedições de conquista do Rio Paraíba, o presente artigo tenta compreender o papel que foi designado aos quatro frades carmelitas que embarcaram na armada de Frutuoso Barbosa em 1580. Esses religiosos carregavam uma carta escrita por Frei João Cayado, provincial da Província Carmelita Portuguesa, a qual estabelecia as primeiras diretrizes de atuação dos missionários carmelitas calçados em terras portuguesas, além de delegar os poderes necessários aos frades para a consolidação da Ordem de Nossa Senhora do Carmo na América. Baseando-se nessas indicações, os frades metamorfosearam a maneira como atuavam, adaptando-se às demandas locais por meio do aproveitamento das oportunidades que surgiam. Apesar dessas adequações, o objetivo principal da atuação desses religiosos no Brasil não se modificou: atender às demandas espirituais de indígenas e população ordinária. A mesma diretriz que moveu os carmelitas para a América também foi a responsável pela decadência da Ordem e sua quase extinção no Brasil no século XIX. Palavras-chave: carmelitas; catequização; Paraíba.
\end{abstract}

\section{El envío de los carmelitas a la América portuguesa en 1580: la carta de Fray Juan Cayado como una instrucción para la acción}

\section{Resumen}

A partir de la historia de las expediciones de conquista del Río Paraíba, este artículo intenta comprender el rol que se les asignó a los cuatro frailes carmelitas que abordaron la armada de Fructuoso Barbosa en 1580. Estos religiosos llevaban una carta escrita por el Fraile João Cayado, provincial de la Provincia Carmelitana Portuguesa, que estableció las primeras instrucciones operativas a los misioneros carmelitas calzados en tierras portuguesas y delegaba a los frailes las facultades necesarias para la consolidación de la Orden de Nuestra Señora del Monte Carmelo en América. En base a estas indicaciones, los frailes metamorfosearon la manera en que actuaban, adaptándose a las necesidades locales mediante el uso de las oportunidades que se presentaron. A pesar de estos ajustes, el objetivo principal de la actuación de los religiosos en el Brasil no ha cambiado: satisfacer las demandas espirituales de los pueblos indígenas y de la populación común. La misma orientación que trasladó a los carmelitas a la América fue también la responsable por la decadencia de la Orden y su casi extinción en Brasil del siglo 19.

Palabras clave: carmelitas; la catequesis; Paraíba.

\section{Sending carmelites to Portuguese America in 1580: the letter from Friar João Cayado as a guideline for action}

\section{Abstract}

Starting with the narrative of the expeditions to conquer Paraíba River, this article attempts to understand the role assigned to the four carmelite friars who boarded in the fleet of Frutuoso Barbosa in 1580. These religious men carried a letter written by Friar João Cayado, the superior of the Portuguese Carmelite Province, which established the first operational guidelines for the Calced Carmelite missionaries travelling to Portuguese territories, besides delegating the necessary powers to the friars for the consolidation of the Order of Our Lady of Mount Carmel in America. Based on these indications, the friars metamorphosed the way they worked, adapting to the local demands by taking the opportunities that arose. Despite the adjustments, the main goal of the work of these religious men in Brazil, which was to meet the spiritual demands of natives and the ordinary population, did not change. The same guideline that directed the carmelites to America was also responsible for the decay of the Order and its near extinction in Brazil in the 19th century.

Keywords: carmelites; catechizing; Paraíba.

\section{L'énvoi des carmélites à l’Amérique portugaise en 1580: la lettre du Frère João Cayado comme ligne directrices}

\section{Résumé}

En commeçant avec la narrative des expeditions de conquête de la rivière Paraíba, cet article essaie de comprendre le rôle de les quatre frères carmélites qui ont embarqué avec l'escadrile de Frutuoso Barbosa en 1580. Ces religieux portaient une lettre écrite par le Frère João Cayado, provincial de la Province Carmélite Portugaise, en fixant les premières lignes directrices pour lactuation des missionaires carmèlites en terre portugaise et en délèguant des pouvoirs aux frères pour consolider l'Ordre de Notre Dame du Mont Carmel dans l'Amérique. Sur cette base, les frères ont changé leur strategies et actions, en sadaptant aux demandes à mesure que les opportunités surgissaient. En dépit des ajustements, leur objectif principal au Brésil n’a pas changé: rencontrer les demandes spirituelles des indigènes et de la population. Ces directrices ont également été responsables pour la decadence et la quasi-extinction de l'Ordre au Brésil dans le XIXe siècle. Mots-clés: les carmélites; catéchisme; Paraíba. 
A primeira tentativa de conquista do Rio Paraíba foi deveras desastrosa. Em 1574, por ordem de D. Luiz de Brito Almeida, então governadorgeral, o ouvidor-geral e provedor-mor da fazenda do Estado, D. Fernão da Silva, saiu com uma expedição em direção ao rio. Montado a cavalo, contava com uma pequena tropa, formada por portugueses e índios aliados, que o seguia a pé. A armada partiu em busca dos potiguaras no intuito de impor-lhes uma reprimenda por suas ações belicosas contra os colonizadores. $\mathrm{O}$ ataque foi malfadado e os sobreviventes tiveram que fugir pelas areias da praia, onde foram perseguidos de perto pelos indígenas. ${ }^{1}$

A relação com os potiguaras já havia sido amistosa. Com a ajuda desses autóctones, os portugueses conseguiram derrotar os caetés, grupo que habitava o litoral da Capitania de Pernambuco quando as primeiras naus vindas de Portugal lá aportaram. Os potiguaras aproveitaram-se da chegada dos portugueses e do interesse lusitano nas terras dos rios Capibaribe e Beberibe para destruir seus inimigos históricos, os caetés. Ao mesmo tempo que os indígenas eram a barreira a ser vencida para a ocupação do território, eles também faziam parte da solução encontrada para suplantar esse obstáculo, participando das guerras que limpavam o terreno da presença de autóctones belicosos que, caso não fossem mortos em combate, integrariam a colonização como escravos.

Os potiguaras habitavam as terras ao redor do rio de águas ruins, significado de "Paraíba" em tupi, ${ }^{2}$ além de também dominarem a Serra da Copaoba, como era chamada a atual Serra da Borborema. As margens do rio formavam um porto seguro para os autóctones porque, além de constituírem uma área estratégica para a defesa de invasores externos e internos, também era nesse local onde os indígenas negociavam o "pau de tinta" — também conhecido como "pao Brazil" — com corsários franceses com quem mantinham profícuo escambo.

A base econômica que movimentava o comércio exportador no século XVI era formada pelo extrativismo da madeira com miolo cor de brasa e pela produção de açúcar, feita por meio da importação e adequação da cana-de-açúcar asiática ao solo da região. Empreendimento caro, a constituição de um engenho exigia um bom cabedal de seu dono, sendo imprescindível uma quantidade razoável de terras agricultáveis que servissem para o plantio da cana-de-açúcar. Ademais, era necessário produzir gêneros de subsistência que seriam utilizados no abastecimento cotidiano do engenho.

Diogo Dias foi um desses homens que decidiu se tornar senhor de engenho na América portuguesa. Descrito pela historiografia como um homem de cabedal, não se sabe ao certo se suas riquezas provinham do comércio ou da agricultura. Independentemente da origem de suas posses, o queinteressa no momentoé conhecer

\footnotetext{
'As expedições para conquista das terras do Rio Paraíba estão descritas no Sumário das Armadas, documento de autoria anônima, escrito entre 1585 e 1587. Uma análise mais apurada desse documento pode ser encontrada em: Adriel Fontenele Batista, O Sumário das Armadas: guerras, visão e estratégias discursivas na conquista da Paraíba, Dissertação de mestrado, Universidade Federal do Rio Grande do Norte, Natal, 2012. Disponível em: <http://repositorio.ufrn.br:8080/jspui/bitstream/1/8784/1/AdrielFB_DISSERT.pdf>. Acesso em: 10 de julho de 2013. Para uma análise das cinco expedições de conquista do Rio Paraíba, relacionando-as com a necessidade de expansão da produção açucareira da capitania de Pernambuco, ver: Regina Célia Gonçalves, Guerras e açúcares: política e economia na capitania da Paraíba, 1585-1630, Bauru, Edusc, 2007.

¿2Os índios chamavam o rio de "Paraíba" devido à constante agitação de suas águas, que os impedia de navegá-lo com suas canoas.
} 
o seu derradeiro empreendimento: um engenho às margens do Rio Goiana, também chamado de Capibaribe-Mirim, onde "conseguiu não apenas plantar canaviais e construir casas e fábricas de açúcar, mas também erguer fortaleza e paliçada para a defesa das suas terras".3 Arregimentou índios para trabalharem na propriedade elá se estabeleceu com sua família e mais alguns colonos. O povoamento dessas terras representava a expansão da ocupação açucareira para territórios que se localizavam na fronteira dos domínios potiguaras. O rápido esgotamento de algumas áreas litorâneas e a constante necessidade de aumentar a produção tornavam as terras do Rio Capibaribe-Mirim necessárias para manter a contínua expansão da lavoura açucareira da Capitania de Pernambuco, visto que o fabrico e o comércio do açúcar estavam em plena ascensão, exigindo a ampliação das áreas de plantio.

A construção de um engenho, às margens do Rio Goiana, ou Capibaribe-Mirim, na fronteira com os Potiguaras, no início dos anos setenta, significava um passo importante para a definitiva ocupação da área pelos portugueses, mesmo porque a iniciativa de Diogo Dias estimulava outros moradores de Itamaracá e de Pernambuco a fazerem o mesmo. ${ }^{4}$

Com a invasão das terras do Rio Capibaribe-Mirim, quebrava-se o tênue armistício entre portugueses e potiguaras. O próximo passo lógico era continuar a expansão da lavoura para a região do Rio Paraíba.

A luta por territórios estava no cerne da cultura indígena; assim, a invasão de suas terras constituiu uma verdadeira declaração de guerra para os potiguaras. Ademais, no século XVI, os engenhos utilizavam majoritariamente a mão-de-obra indígena; portanto, converter as terras potiguaras em plantações de cana-de-açúcar significava também transformar os índios em trabalhadores das unidades açucareiras, fosse pela escravidão ou pela prestação de serviços. Ou seja, o elemento indígena era fator crucial que interferia diretamente no sucesso da colonização na América portuguesa.

A reação à construção do engenho de Diogo Dias veio em 1574, quando os potiguaras promoveram uma chacina ao invadirem e destruírem o Engenho Tracunhaém. Em 1575, o governador D. Luiz Brito de Almeida montou um pequeno exército em Salvador para conquistar o rio de águas ruins pessoalmente. Equipou uma armada e partiu em uma nau que retornaria à Bahia sem nunca ter tocado as terras do Rio Paraíba: os maus ventos obrigaram o governador e sua tripulação a voltarem para o lugar de onde vieram.

Uma nova expedição somente seria organizada em 1579. Problemas enfrentados como o alto custo da armada capitaneada por D. Luiz e a questão sucessória portuguesa, que absorveria a atenção de Portugal após a morte do rei D. Sebastião I na batalha de Alcácer-Quibir em 1578, explicam a postergação da conquista do Rio Paraíba. Nesse ínterim, a situação só se agravou para os portugueses: os sucessivos ataques indígenas praticamente esvaziaram a Capitania de Itamaracá e toda a população viu-se obrigada a se refugiar na Ilha de Itamaracá, enquanto

${ }^{3}$ Regina Célia Gonçalves, Guerras e açúcares: política e economia na capitania da Paraíba, 1585-1630, Bauru, Edusc, 2007, p. 69.

4/bidem, p. 68. 
os potiguaras beiravam os limites da Capitania de Pernambuco ameaçando o povoamento português na região. O processo de ocupação do território das capitanias do norte do Estado do Brasil encontrava-se em xeque e os portugueses corriam o risco de perderem as terras e o dinheiro que haviam investido na região.

$\mathrm{O}$ avanço potiguar sobre áreas açucareiras da capitania de Pernambuco indicava claramente que a ocupação das terras americanas pelos portugueses só poderia se concretizar com a subjugação do elemento indígena.

Alarmado pelas graves notícias que vinham das capitanias do norte, o então rei de Portugal, Cardeal D. Henrique, autorizou a constituição de uma nova armada com a finalidade de conquistar o Rio Paraíba e pôr um fim à ameaça potiguara. Sem recursos para financiar a empreitada, a solução encontrada foi estabelecer uma parceria com um particular que se interessasse pela exploração daquelas terras, prometendo o cargo de capitão daquele território pelo período de dez anos a partir de sua conquista.

Eu, el Rey, faço saber aos que este alvará virem que mando ora a Fructuoso Barbosa a povoar as terras da Paraíba nas partes do Brasil e lançar o rio dellas os corsários que ahi estão e as tem ocupado o qual leva consigo alguns moradores deste reino para viverem nellas pelo que hei por bem que o dito Fructuoso Barbosa seja o capitão de toda dita gente e da gente da navegação dos navios que com elle vão assim na viagem no mar como depois que chegar às ditas terras e estar nellas todo o tempo que nellas poder estar e assim hei por bem que elle seja capitão da fortaleza e povoação nas ditas terras fizer e isto por tempo de dez annos não mandando eu primeiro o contrário. ${ }^{5}$

Como é dito no documento, Frutuoso Barbosa veio com a atribuição de conquistar e povoar as terras do Rio Paraíba. Para que tal feito se efetivasse, trouxe consigo alguns moradores, dentre os quais, quatro frades carmelitas. ${ }^{6}$ Foram os primeiros religiosos da Ordem de Nossa Senhora do Carmo a se dirigirem à América portuguesa.

Foi o geral da Ordem, Frei João Cayado, quem autorizou a vinda dos religiosos na armada organizada por Frutuoso Barbosa. A carta que enviou os quatro carmelitas para a América portuguesa foi originalmente escrita em latim e até hoje não pôde ser localizada nos fundos arquivísticos. Seu conteúdo só chegou aos dias atuais porque, no início do século XVIII, frei Manoel de Sá optou por incluir sua tradução completa na crônica que escrevia sobre a Ordem de Nossa Senhora do Carmo. A carta é uma espécie de certidão de nascimento do projeto missionário do Carmelo nas terras lusitanas.

\footnotetext{
${ }^{5}$ Cônego Florentino Barbosa, "Documentos Históricos", Revista do Instituto Histórico e Geográfico Paraibano, vol. 10, João Pessoa, 1946, p. 173-174.

${ }^{6}$ Em 1593, a Ordem de Nossa Senhora do Carmo dividiu-se em duas: a Descalça, fruto da Reforma Teresiana promovida por Santa Teresa de Jesus no século XVI, e a Calçada, fundada no final do século XI e que, a partir do século XVII, passaria a conviver com duas constituições diferentes: a da Antiga Observância e a da Estrita Observância, essa última oriunda da Reforma Turônica no século XVII. Sobre esse assunto, ver: André Cabral Honor, Universo cultural carmelita no além-mar: formação e atuação dos carmelitas reformados nas capitanias do norte do Estado do Brasil (sécs. XVI a XVIII), Tese de doutorado, Universidade Federal de Minas Gerais, Belo Horizonte, 2013; Maria das Graças Souza Aires Araújo, Carmelitas em Pernambuco: fixação e expansão, Dissertação de mestrado, Universidade Federal de Pernambuco, Recife, 2000.
} 
Mestre Fr. João Cayado, Vigario Provincial da Ordem de N. Senhora do Carmo, neste Reyno de Portugal, \&c. por quanto he nossa obrigaçaõ, e de todos os Religiosos, que professaõ nosso modo de vida, servir a Deos, e a sua Mãy Santissima, applicandonos com todo cuidado a salvaçaõ das almas, e augmento da Religião Christaã, e vendo nós que será muito do agrado do mesmo Senhor, e utilidade assim dos proffesores da verdadeyra Fé como aos faltos da sua luz, q habitaõ os lugares do Brazil, e caressem decopia de Sacerdotes, que a huns instruaõ nos preceytos de Christo, e a outros administrarem o Sacramento da Penitencia, movidos nós assim da Caridade para com o próximo, como da obrigação do nosso Ofício, e do obsequio que devemos fazer ao nosso Christianissimo Rei Dom Henrique, a quem he muito agradavel a extensão do nosso nome nas partes do Brazil, como nos fez presente, e ao seu insigne Capitão Fructuoso Barbosa encomendou que solicitasse com todo o cuidado o levarnos em sua companhia como elle com tanto afecto tem feyto; mandamos aos Religiosissimos Padres Fr. Domingos Freyre, Fr. Alberto, Fr. Bernardo Pimentel, e Fr. Antônio Pinheyro, todos varões de provada Religião, sacerdotes Professos da nossa Ordem, que acompanhem ao sobredito capitão, na viagem que se hade fazer para edificar a Cidade da Parahiba, aonde poderão fundar mosteiro desta Ordem, a que intitularão Nossa Senhora da Victoria: e não só nesta terra, mas também em Pernambuco, e em todos aquelles lugares, que lhe offerecerem, sendo convenientes ao serviço de Deos, e das almas dos proximos, e bem da religião; e nas taes regioens o Padre Fr. Domingos Freire pregará o Evangelho de Christo, e ouvirá de confissão, e os demais padres seus companheiros, se parecer assim ao Reverendissimo Ordinario do Lugar, e executarão os demais Officios, assim de Sacerdotes, como de Religiosos, e constituimos para seu Vigario ao padre Fr. Domingos Freire, ao qual terão obediencia, erespeyto como devem a seu Prelado, elhe commetemos as nossas vezes, e poderes, elhe damos o cuidado dos ditos Religiosos, assim no temporal como no espiritual, e poderaõ por commissaõ do nosso Reverendissimo P. Geral mestre João Baptista Rubeo de Ravena receber á nossa Irmandade todos aquelles, que com piedade, e devoção a pedirem, e dar aos irmãos as letras concedidas pelo Papa Clemente VII, e confirmada pelo papa Gregorio XIII, e não só fará isso, mas tudo mais o que nós fizéramos, se presente estivessemos, seguindo sempre as Ordens do Reverendo Padre Prior do nosso Convento em Lisbôa, ao qual determinadamente obedeceraõ, em quanto no capítulo Provincial senaõ determinar o contrário, e pedimos com toda aquella submissão, e caridade, que devem a Irmãos, ao Reverendissimo Bispo do Brazil, e a seus Curas e Vigários que aos sobreditos Padres recebam com a benignidade, \& caridade devida ao seu Officio, e uzem de seu ministerio e industria para saúde das almas, e assim não só alcançarão grande premio da caridade, que uzarem com todos os seus, mas também da que observarem com estes quatro. Dada neste nosso Convento de Lisboa sub nosso sinal, e sello do nosso Officio em vinte e seis de Janeyro de 1580. M. Frey Joaõ Cayado. ${ }^{7}$

FFrei Manoel de Sá, Memórias históricas da Ordem de Nossa Senhora do Carmo da Provincia de Portugal, Lisboa Oriental, Offycina Josep. Antonio da Silva, 1727, p. 33-35. Escrita em dois tomos, a segunda parte da crônica de Frei Manoel de Sá perdeu-se em 1755, quando o grande terremoto de Lisboa, seguido pelo tsunami, destruiu por completo o convento carmelita da cidade e seu precioso arquivo. Segundo o próprio Manoel de Sá revela no prefácio do primeiro volume, o segundo versaria sobre a presença carmelita no além-mar. 
Cientes da importância que os missionários tinham na consolidação da colonização, principalmente no trato com os indígenas, Frutuoso Barbosa, como futuro senhor das terras do Paraíba, cedeu aos carmelitas o direito de fundar o primeiro convento na cidade a ser edificada, que deveria ser consagrado a Nossa Senhora da Vitória. Dessa maneira, o monumento religioso também serviria de marco da conquista do Rio Paraíba e da consequente derrota dos indígenas, além de promover em terras lusitanas o culto da "Mãy Santissima"8 de Deus. A invocação do convento sugeria o destino dos potiguaras: sua derrota por meio da guerra justa, que se traduzia no extermínio ou escravização desses indígenas.

\section{Os potiguaras aproveitaram-se da chegada dos portugueses e do interesse lusitano nas terras dos rios Capibaribe e Beberibe para destruir seus inimigos históricos, os caetés}

Frei João Cayado esclarece que o clero regular possuía a obrigação de expandir a fé cristã pelo mundo e que, a pedido do rei português, os carmelitas deveriam também catequizar as partes do Brasil. Os frades da Ordem de Nossa Senhora do Carmo acrescentaram uma especificidade às suas motivações: além de terem a obrigação de servir a Deus, razão principal que move qualquer membro do clero regular, deveriam servir a Nossa Senhora, matrona da Ordem. Nas capitanias da Paraíba $(\mathrm{CPb})$ e Pernambuco (CPe), as igrejas fundadas pelos carmelitas tiveram predominantemente invocações marianas: Nossa Senhora do Carmo (Cidade da Paraíba, CPb; Recife, Cabo de Santo Agostinho e Hospício do Arraial, CPe); Nossa Senhora do Desterro (Olinda, CPe/Carmelitas Descalços); Nossa Senhora da Guia (Hospício de Lucena, CPb); Nossa Senhora da Piedade (Hospício da Piedade, CPe); Nossa Senhora da Luz (Hospício do Japomim, CPe); Nossa Senhora da Conceição (Hospício do Jiqui, CPe). As exceções são: a Igreja da Ordem Primeira Carmelita de Goiana (Capitania de Itamaracá), que possui invocação a Santo Alberto, e a Igreja Carmelita da Ordem Primeira de Olinda (CPe), que possui invocação a Santo Antônio.

Na carta de Frei João Cayado, a população da América é dividida em dois tipos: os faltosos da "verdadeyra fé", uma referência aos negros da terra, e os já cristianizados que necessitavam de guias espirituais para o exercício do catolicismo.

Apesar de ainda não terem chegado à América portuguesa, o processo de tradução entre indígenas e missionários já havia começado, pois as notícias do contato afluíam pela Europa.

${ }^{8}$ Todas as citações sem referência remetem-se à carta transcrita de Frei João Cayado. 
O trabalho de evangelização e o de aprendizado do cristianismo foram um contínuo movimento de mudanças rápidas e reajustes incessantes de sistemas simbólicos, de um e de outro lado, para que eles pudessem continuar a fazer sentido num mundo que não era mais o mesmo onde aqueles sistemas se formaram. Nunca houve, do lado indígena, a aceitação passiva e a absorção indiscriminada da fé imposta pelos missionários, e tampouco houve um fenômeno de "resistência" entendida como negação total da catequese e afirmação de seus costumes tradicionais, ou "volta" a eles. O que houve foi um processo de negociação ou, para dizer melhor, de "tradução", o que houve foi a escolha de estratégias para solucionar o problema, linguístico e cultural, de reconhecer no "outro" elementos redutíveis ao mundo cultural do "eu".

A circulação desses saberes proporcionava às pessoas que nunca tiveram contato com os autóctones da América, como Frei João Cayado, uma visão europeizada dos indígenas que se modificava à medida que o contato avançava. "A extraordinária coincidência destas observações, é bom lembrar, depende menos de uma coincidência de fatos observados do que da circulação de relatos entre os escritores." ${ }^{10}$ A ideia de um povo que "não tem Fé, nem Lei, nem Rei"11 já era descartada pelos carmelitas ao falarem da necessidade de "proffesores da verdadeyra Fé como aos faltos da sua luz, q habitaõ os lugares do Brazil, e caressem decopia de Sacerdotes, que a huns instruaõ nos preceytos de Christo [...]."

A ideia informadora é a máxima de Cícero, retomada pela escolástica, de que não há povo, por mais bárbaro que seja, que não tenha em si uma noção mínima de divindade. O ponto de partida e de chegada coincidem: a religião, a crença, é um fato universal. O problema será transformar a "crença" na verdadeira $F e ́$, transformando ao mesmo tempo a "barbárie" em civilização. ${ }^{12}$

As notícias sobre a experiência jesuítica junto aos indígenas é fator fundamental na construção do pensamento de Frei João Cayado, que ignora as informações dos primeiros cronistas, entregando uma visão posterior, fruto já do processo de tradução que havia entre missionários e autóctones, o qual atribuía alguma noção de fé aos indígenas.

Os recém-enviados religiosos carmelitas também possuíam a atribuição de evangelizar a população portuguesa que vivia nas vilas e cidades, estabelecendo o catolicismo como base de identificação entre o centro diretor português e o território americano. Para essa finalidade, se estabeleciam em

\footnotetext{
9Maria Cristina Pompa, Religião como tradução: missionários, Tupi e "Tapuia" no Brasil colonial. Tese de doutorado, Universidade Estadual de Campinas, Campinas, 2001, p. 90. Disponível em: <http://www. bibliotecadigital.unicamp.br/document/?code=vtls000220275>. Acesso em: 6 de setembro de 2014 10/bidem, p. 28.

"Pero de Magalhães de Gândavo, A primeira história do Brasil: história da província de Santa Cruz a que vulgarmente chamamos Brasil, Rio de Janeiro, Jorge Zahar, 2004, p. 135.

${ }^{12}$ Paula Montero (org.), Deus na aldeia: missionários, índios e mediação cultural, São Paulo, Globo, 2006, p. 117.
} 
templos, geralmente nas partes mais altas das vilas e cidades, onde celebravam missas, administravam sacramentos e promoviam festas e procissões que atraíam os fiéis à devoção a personagens e elementos da cultura histórica daquela Ordem. ${ }^{13}$

Professar uma religião poderia até ser uma tarefa fácil; difícil era manter a conduta cristã no cotidiano. Para coibir o pecado e a influência do demônio, o Concílio de Trento recomendava o sacramento da penitência.

\begin{abstract}
Se em todos os regenerados houvesse tal gratidão para com Deus que conservassem constantemente a justiça recebida no batismo por benefício e graça sua, não seria necessário outro sacramento instituído para remissão dos pecados diferente deste [cân. 2]. Mas como "Deus, rico em misericórdia" [Ef 2,4] "conheceu a fragilidade de nossa origem" [Sl 103,14], quis também conceder um remédio vivificante aos que se entregassem de novo à escravidão do pecado e ao poder do demônio, a saber: o sacramento da penitência [cân. 1], pelo qual se aplica o benefício da morte de Cristo aos que caem depois do batismo. ${ }^{14}$
\end{abstract}

Em consonância com os preceitos tridentinos, quando se tratava da manutenção da fé e coibição dos desvios de conduta, os frades carmelitas deveriam "administrar o Sacramento da Penitência", que, de acordo com a 14 a sessão do Concílio de Trento, de 25 de novembro de $1551,{ }^{15}$ era composto por três etapas: contrição (dor da culpa pelo pecado cometido), confissão (relato do ato ímpio a um sacerdote) e satisfação (pena designada). A expurgação dos pecados só poderia dar-se por completa após a aplicação de um "castigo", que precisava ser bem dosado para que servisse de lição ao penitente, restabelecendo, dessa forma, o seu elo com Cristo.

\footnotetext{
${ }^{13}$ Entende-se como cultura histórica o acúmulo de materiais, físicos e mentais, produzidos e acumulados pelo homem ao longo do tempo, diferenciando-se, mas, ao mesmo tempo, mesclando-se com a cultura historiográfica. "Finalmente, o conceito de Cultura Histórica que, salvo se quisermos ser enfáticos, é circular e redundante em sua substantivação e em sua adjetivação: toda Cultura é histórica e tudo que é histórico, é cultural. [...] Compreendida como o conjunto da produção e reprodução da existência humana, a Cultura se insere, pois, em duas dimensões sem as quais não se realiza: o tempo e o espaço. E não se realiza, obviamente, sem um agente: o Homem, em sociedade, cuja capacidade de ideação reflexiva (e não reflexa) possibilita a mediação com a natureza, produzindo a segunda natureza (Marx), ou a natureza culturalizada que, por sua vez, produz o Homem. Neste processo, a Cultura se faz enquanto 'um palimpsesto multiforme', no dizer de Carlos Antonio Aguirre Rojas porque inclui sistemas adaptativos, cognitivos e simbólicos; implica na produção de artefatos materiais e simbólicos; envolve múltiplos agentes; abrange a produção, circulação, transmissão e recepção dos saberes e fazeres humanos; requer processos socializadores para a transmissão das tradições e as elaborações criativas. Em síntese: é o conjunto das experiências vividas pela Humanidade e os sentidos que os seres humanos dão ao mundo. Assim, a Cultura Histórica guarda duplo sentido: um, genérico, enquanto produção pela História-processo; outro, mais específico, como História-conhecimento, melhor nomeada, talvez, de Cultura Historiográfica. Portanto, toda Cultura Histórica contém uma Cultura Historiográfica, esta última entendida como o conjunto das representações formuladas sobre as experiências vividas pelas sociedades, os grupos sociais, as pessoas, em uma perspectiva de temporalidade". Rosa Maria Godoy Silveira, "A cultura histórica em representações sobre territorialidade", Revista de História Saeculum, n. 16, João Pessoa, 2007, p. 42

${ }^{14}$ Heinrich Dezinger, Compêndio dos símbolos, definições e declarações de fé e moral, São Paulo, Paulinas; Loyola, 2007, p. 426-427.

${ }^{15} \mathrm{O}$ texto completo da "Doutrina sobre o sacramento da penitência" encontra-se em: Ibidem, p. 426-436.
} 
Mas, de forma curiosamente paralela à ocupação do território, desde logo se percebeu que a simples marca de uma conquista/ conversão, na sua representação do processo de cristianização, criava mais problemas que resolvia. Para tentar resolver esses problemas foi necessário introduzir a confissão, no lugar do batismo, como verdadeira porta de acesso ao Cristianismo. [...] E o novo corretivo - de uma catequese destinada a corrigir oferecendo uma adequada consciência dos deveres, morais e civis, do (novo) cristão - apareceu como o instrumento essencial para converter não somente as populações selvagens americanas, mas também as massas de "infiéis" e de camponeses não letrados que iam sendo descobertos, cada vez com maior preocupação, dentro da própria Europa cristã. ${ }^{16}$

Os problemas enfrentados pela conversão, por meio do batismo junto aos autóctones americanos, refletiram no modus operandi das missões na Europa, que, por sua vez, reverberou na atuação do clero regular junto à população dita cristã das Américas. Enfatizava-se a aplicação do sacramento da penitência como ferramenta de manutenção da fé. Isso não diminuía a importância do batismo, pois, de acordo com o Concílio de Trento, "a Igreja não exerce jurisdição sobre a pessoa que não tenha primeiro entrado pela porta do batismo." ${ }^{17}$

\section{A luta por territórios estava no cerne da cultura indígena; assim, a invasão de suas terras constituiu uma verdadeira declaração de guerra para os potiguaras}

No contexto da expansão ultramarina, a religião católica criava o vínculo entre Portugal e a América. Os frades estavam a serviço do rei, como explicita Frei João Cayado, "movidos nós assim da Caridade para com o próximo, como da obrigação do nosso Ofício, e do obsequio que devemos fazer ao nosso Christianissimo Rei Dom Henrique". A instituição do padroado unia o Estado português e a Igreja Católica em sua atuação no além-mar.

O padroado português pode ser amplamente definido como uma combinação de direitos, privilégios e deveres concedidos pelo papado à Coroa de Portugal como patrona das missões e instituições eclesiásticas católicas romanas em vastas regiões da África, da Ásia e do Brasil. ${ }^{18}$

\footnotetext{
${ }^{16}$ Adone Agnolin, Jesuitas e selvagens: a negociação da fé no encontro catequético-ritual americano-tupi (séculos XVI-XVIII), São Paulo, Humanitas, 2007, p. 25.

${ }^{17 H e i n r i c h ~ D e z i n g e r, ~ C o m p e ̂ n d i o ~ d o s ~ s i ́ m b o l o s, ~ d e f i n i c ̧ o ̃ e s ~ e ~ d e c l a r a c ̧ o ̃ e s ~ d e ~ f e ́ ~ e ~ m o r a l, ~ S a ̃ o ~ P a u l o, ~ P a u l i n a s ; ~}$ Loyola, 2007, p. 428

${ }^{18}$ Charles R. Boxer, O império marítimo português: 1415-1825, São Paulo, Companhia das Letras, 2002, p. 243.
} 
Com o título vitalício de Mestre da Ordem de Cristo, o rei português era responsável por arrecadar o imposto eclesiástico do dízimo, ao mesmo tempo em que se responsabilizava pela expansão da Igreja na América, Ásia e África. A necessidade de fomentar o catolicismo na América portuguesa visava garantir a aplicação de uma norma de conduta europeia cuja finalidade maior era submeter todos à ordem social portuguesa. Ao converter essa população à religião católica, estabelecia-se o elo que respaldava a autoridade do monarca português em terras tão longínquas. Assim, desde os primórdios da colonização efetiva da América, tencionava-se incorporar uma imberbe elite local ao reino português, que, por sua vez, passou a tomar para si os ideais de vida e nobreza europeus, mesmo quando não possuíam esses atributos de nascença. "O poder tinha o dom mágico de purificar o sangue e mudar a cor da pele." ${ }^{19}$

\section{Ao converter essa população à religião católica, estabelecia-se o elo que respaldava a autoridade do monarca português em terras tão longínquas}

Nesse processo civilizador, os carmelitas enfatizavam o culto a Nossa Senhora do Carmo, estabelecendo uma identificação que aproximava os habitantes do Brasil a Portugal, mas também à Ordem Carmelita. Era por meio da cultura histórica carmelita que os frades do Carmelo moldavam o elo que identificava a América com o monarca que reinava sob um país fundado sob os auspícios de Deus. "Portugal, portanto, deve sua fundação a uma intervenção especial de Deus e tem, em consequência, uma finalidade especificamente religiosa". ${ }^{20}$

A tradução do documento feita por Frei Manoel de Sá reforça a hipótese de que a Cidade da Paraíba já estava fundada, porém ainda não existia. No latim eclesiástico, as palavras "edificar" e "fundar" são postas de maneiras diferentes: a primeira se relaciona diretamente a uma construção física; para isso, utilizase o verbo aedifico. Já para fundar, significando o ato de criar ou de instituir algo, distanciando-se do sentido de construção física, é mais comum o uso do verbo fundo. Frei Manoel de Sá era um religioso de renome, famoso pelos seus estudos; portanto, é factível pensar que o carmelita conhecia a diferença entre os verbos aedifico e fundo, traduzindo-os com o sentido correto. Caso essa hipótese seja verdadeira, a Cidade da Paraíba já se encontrava fundada antes de 1580 , porém não se encontrava edificada. ${ }^{21}$

\footnotetext{
${ }^{19}$ Evaldo Cabral de Mello, O nome e o sangue: uma parábola genealógica no Pernambuco colonial, São Paulo, Companhia das Letras, 2009, p. 238.

${ }^{20}$ Luís Palacin, Vieira e a visão trágica do Barroco, São Paulo, Hucitec, 1986, p. 36.

${ }^{21}$ Tais afirmações se sustentam em: Leo F. Stelten, Dictionary of ecclesiastical Latin: with an appendix of Latin expressions defined and clarified, Peabody, MA. Hendrickson, 2011; Francisco Torrinha, Dicionário Latino Português, 8. ed., Porto, Reunidos, [s.d].
} 
Na impossibilidade de recorrer ao documento original, o historiador deve tomar como indícios para suas considerações as pequenas minúcias que, por vezes, a documentação deixa escapar. No Sumário das Armadas, documento que narra a conquista do Rio Paraíba, é bem clara a colocação do artigo "o" quando o texto se refere ao rio, e do artigo "a" quando se refere à capitania: "Pois as outras varzeas que ha entre Pernambuco e $a$ Parahiba e fazem ao longo dos rios que entra essas duas capitanias mais pegadas ao Parahiba [...] (grifos do autor)".22 Seguindo a mesma lógica de raciocínio, o que é bastante factível, dada a proximidade temporal entre os documentos (o Sumário das Armadas foi escrito entre 1585 e 1587), a pequena série de cartas de 1581 escritas por El Rei sobre Frutuoso Barbosa e sua armada possui a mesma estrutura sintática, se referindo como a Paraíba, e não o Paraíba: "No que toca a madeyra do Brasil e ida do Frutuoso Barbosa povoar $a$ Parayba [...]" (grifo do autor) ${ }^{23}$; "Frutuoso Barbosa que ya povoar $a$ Parayba nas partes do Brasil arribou com muita gente nessa" (grifo do autor) ${ }^{24}$ Nas duas cartas restantes, o rei se refere a Frutuoso Barbosa como "capitão da gente da povoação da Parahiba nas partes do Brasil"25; "capitão da gente da povoação da Parahiba das partes do Brasil que ora mando com o dito cargo as ditas partes".26 É necessário investigar que cargo seria esse, se a palavra "povoação" se referia a um núcleo habitacional, como creio que seja mais lógico, já que as pessoas estavam referidas na palavra "gente", ou ao elemento humano - aqueles que iriam morar na Capitania da Paraíba -, o que resulta em uma redundância de grafia.

Em seu Diálogos chronológicos, históricos, panegíricos, ascéticos sobre os frutos principaes e felizes progressos da ordem do Carmo Calçado em Portugal, Frei Miguel de Azevedo escreve: "O Cardeal Rei D. Henrique quis fundar a Paraíba, escreveo ao provincial de carmo recomendando-lhe que destinasse relligiosos de sciencia e de consciencia para exercerem o sagrado ministerio das terras daquella nova fundação". ${ }^{27}$ Ou seja, haveria o desejo de fundar a Paraíba; contudo, há de se ter muito cuidado com essa informação, pois o manuscrito é da segunda metade do século XVIII e suas informações provêm de outras fontes secundárias. Apesar de apontar para a ideia de que havia uma ficção jurídica de que a Capitania da Paraíba já se encontrava criada, pelo menos a partir de 1581, não é possível afirmar isso com toda certeza. Todavia, tais dados servem para levantar dúvidas sobre a data oficial de fundação da Paraíba em 5 de agosto de 1585.

A carta expressa que o próprio Cardeal D. Henrique teria solicitado ao Convento de Lisboa o envio de missionários na empreitada para edificar a

${ }^{22}$ Anônimo, Sumario das Armadas que si fizerão e guerras que se derão na conquista do Rio Parahiba escripta e feito por mandado do muito reverendo Padre em Christo o padre Cristóvão de Ganvia visitador da Companhia de Jesus de toda a Província do Brasil. Disponível em: <http://www.carlamaryoliveira.pro.br/1585 sumario_das_armadas.html . Acesso em: 29 de março de 2013.

${ }^{23}$ Palácio Nacional da Ajuda (PNA), Cota: 49-x-4, fl. 264v.

${ }^{24}$ /bidem, fl. 338

25/dem, Cota: 49-x-I, fl. 343

${ }^{26} /$ bidem, fl. 344.

${ }^{27}$ Academia de Ciências de Lisboa, Cota: Ms. 86. 
Cidade da Paraíba. Os carmelitas enviados não eram apenas frades, mas também clérigos ordenados, ou seja, estavam aptos a realizar missas e administrar sacramentos mesmo em locais onde já havia uma diocese, ${ }^{28}$ atribuições fundamentais em uma terra que carecia de religiosos. Para poderem cumprir seu papel missionário, necessitavam de um edifício onde pudessem fundar uma casa conventual, estabelecendo seu modus vivendi.

No século XVI, não era necessário ir muito longe para realizar a catequização dos naturais que habitavam os arredores dos núcleos populacionais. Pioneiros na experiência missionária na América portuguesa, os jesuítas já desenvolviam o sistema de aldeamentos em detrimento das missões volantes que se mostravam pouco frutíferas, pois os índios retornavam a seus costumes assim que os missionários deixavam as aldeias.

Procurando adaptar-se a esses índios, "sem fé, sem lei, sem rei", os jesuítas do Brasil promoveram a experiência da fixação da missão na aldeia. A fixação implicou uma transformação do ideal missionário original, que concebia a missão como uma experiência de itinerância e miséria. Fixando-se entre os índios e assumindo sua administração espiritual, o missionário se assemelhava a um cura. [...] A fixação do missionário entre os índios lhe conferiu também de fato um estatuto político de administrador deles: ele era aquele que organizava o trabalho dos índios, especialmente em benefício da Companhia, e assegurava sua submissão política ao poder colonial pelo viés do constrangimento e castigos físicos. ${ }^{29}$

Entretanto, esse sistema exigia um largo número de religiosos, que deveriam morar nos aldeamentos juntos aos índios, mantendo-os sob vigilância. O insuficiente número de frades e a grande quantidade de indígenas a serem catequizados justificam a larga utilização das missões volantes que perduraram até o século XVIII como forma de auxiliar a evangelização dos índios. Porém, antes de se estabelecerem em algum aldeamento, esses quatro religiosos precisavam expandir a Ordem de Nossa Senhora do Carmo na América, arregimentando noviços e prestando bons serviços à sociedade local, ao monarca e a Deus.

A carta de Frei João Cayado não eliminava a possibilidade de os carmelitas se estabelecerem em outros lugares e citava a Capitania de Pernambuco como um possível local onde poderiam fundar um convento. Os frades deveriam aceitar qualquer lugar que lhes oferecessem ou onde fossem úteis ao serviço da Igreja e, portanto, ao Estado português. Com essa possibilidade, o provincial desobrigava os frades a participarem da guerra de conquista do Rio Paraíba, fazendo da armada de Frutuoso uma desculpa e um meio de transporte para a vinda dos primeiros frades carmelitas à América portuguesa.

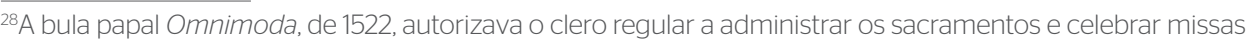
nas Índias em regiões onde não houvesse dioceses, prerrogativa que não se aplicava aos quatro carmelitas por também serem clérigos ordenados.

${ }^{29}$ Charlotte de Castelnau-L'Estoile, Operários de uma vinha estéril: os jesuítas e a conversão dos índios no Brasil: 1580-1620, Tradução de Ilka Stern Cohen, Bauru, Edusc, 2006, p. 531.
} 
Não seria em 1580 que os carmelitas chegariam ao Rio Paraíba. Quando a armada aportou em Olinda, os frades se estabeleceram na vila e desistiram da viagem de conquista. Os habitantes lhes ofereceram uma ermida para cuidar e os carmelitas preferiram não arriscar o pouco que tinham. Entre trocar o certo pelo duvidoso, optaram por permanecer na Capitania de Pernambuco, não seguindo adiante junto à expedição de Frutuoso Barbosa, que também fracassou no intuito de conquistar o Rio Paraíba. A única exigência feita aos frades para a doação da ermida foi de que mantivessem a invocação do pequeno templo a Santo Antônio de Pádua, daí porque a Igreja Carmelita de Olinda ficou consagrada a um santo franciscano, contrariando o costume de homenagear algum personagem relacionado à Ordem.

\section{No século XVI, não era necessário ir muito longe para realizar a catequização dos naturais que habitavam os arredores dos núcleos populacionais}

Quem eram esses religiosos que se estabeleceram em Pernambuco? Sobre suas biografias, sabe-se muito pouco. Frei Domingos Freyre era um religioso muito bem quisto dentro do Convento de Lisboa, "de grande virtude, e letras, insigne pregador daquelle tempo [...]".30 O destaque para um homem de letras e sábio orador ressalta o papel da oralidade na conversão e manutenção da fé. Além do mais, ser um homem de letras tornava-o apto a ensinar gramática e doutrina cristã para os iletrados e todos os que desejassem adentrar a ordem, desde que cumprissem com os demais requisitos necessários. Ao enviar homens letrados, o provincial tornava possível começar assim que aportasse nas terras americanas a arregimentação de noviços para a Ordem de Nossa Senhora do Carmo. Frei Domingos Freire também era nomeado vigário dos carmelitas com plenos poderes temporais e espirituais, ou seja, era responsável pela construção de conventos, seu sustento e tudo o que versasse sobre questões materiais, como também deveria orientar espiritualmente os demais religiosos que o acompanhavam, assim como os que entrassem na Ordem dali por diante. Para esse fim, Frei João Cayado lhe conferia plenos poderes para agir em seu nome, "como se presente estivessemos". ${ }^{31}$

Essa delegação de poderes demonstra que os frades estavam cientes da morosidade de comunicação que havia entre o Brasil e Portugal. Nesse momento inicial, uma série de decisões práticas deveriam ser tomadas, uma vez que não poderiam esperar por um processo de correspondência, como, por exemplo, a decisão de não acompanhar Frutuoso na expedição ao Rio Paraíba, permanecendo no Recife. Mesmo assim, Frei Domingos Freire deveria informar ao

${ }^{30}$ Frei Manoel de Sá, Memórias históricas da Ordem de Nossa Senhora do Carmo da Provincia de Portugal, Lisboa Oriental, Offycina Josep. Antonio da Silva, 1727, p. 33.

31/bidem, p. 35. 
Convento de Lisboa que poderia fazer intervenções no processo de estabelecimento da Ordem na América portuguesa por se tratar do convento cabeça da Província, a quem todas as casas deveriam se reportar.

De acordo com as letras concedidas, os frades estavam aptos a aceitar homens locais dispostos a virarem noviços, porém "era proibida a admissão à Ordem de índios ou de mouros".32 Ao aceitar a presença de pessoas nascidas na América, a Ordem abria as portas de sua instituição para a entrada de habitantes locais, dentre os quais estavam os mestiços, muitos deles filhos e parentes das elites locais. Em um futuro não muito distante, a cooptação dessas pessoas ao que os próprios frades chamaram de "religião carmelita" significaria uma maior facilidade na obtenção de mercês e privilégios em detrimento das demais ordens religiosas. Ademais, os carmelitas já pareciam perceber que a quantidade de missionários dispostos a viverem no além-mar era insuficiente para atender a demanda, daí a importância de doutrinar pessoas da região para que servissem de vetor de multiplicação da fé cristã.

\section{Os carmelitas já pareciam perceber que a quantidade de missionários dispostos a viverem no além-mar era insuficiente para atender a demanda}

As ordens medicantes, dentre as quais se incluem a Ordem de Nossa Senhora do Carmo, foram autorizadas a missionar nas Índias pela já citada bula Omnimoda, de 9 de março de 1522. Quando Frei João Cayado escreveu sua carta em 1580, os carmelitas possuíam pouquíssima experiência com o trabalho missionário, ${ }^{33}$ afinal, tratava-se de uma ordem mendicante cujo apostolado encontrava-se em segundo plano diante da contemplação.

Aunque es Orden $<<$ mixta $>>$ (contemplativa-activa), predomina la vida contemplativa, fin principal y razón de su ser. Todo se organiza en función de esa principalidad: el silencio, la soledad, la austeridad de la vida, la pobreza, etc. El apostolado es secundario, en la medida en que no destruye el carácter contemplativo; pero también necesario, casi como una exigencia del talante contemplativo. ${ }^{34}$

Até o século XVI, os membros da Ordem de Nossa Senhora do Carmo deveriam se ater à contemplação em seus conventos, podendo celebrar missas e

32Balbino Velasco Bayón, História da Ordem do Carmo em Portugal, Lisboa, Paulinas, 2001, p. 185.

${ }^{33}$ Houve algumas tentativas de se implantarem missões nas Índias antes de 1580, com o envio de frades carmelitas para Yucatán, Cartagena (pressupõe-se que seja Cartago e não Cartagena de Indias) e Nova Granada. Contudo, nenhuma dessas tentativas se concretizou em um projeto missionário, pois não se estabeleceram conventos nesses locais. A Ordem Calçada foi proibida, no século XVI, de catequizar na América espanhola devido a essas malfadadas experiências. Sobre essas experiências efêmeras, ver: Joaquín Smet, Los carmelitas: historia de la Orden Del Carmen, las reformas. Personas, literatura, arte, 1563-1750, Tomo III, Madrid, Biblioteca de Autores Cristianos, 1991.

${ }^{34}$ Daniel de Pablo Maroto, Historia de la espiritualidad cristiana, 2. ed., Madrid, Editorial de Espiritualidad, [s.d.], p. 182. 
administrar sacramentos caso fossem clérigos ordenados. Enquanto os jesuítas continham no cerne de suas competências um projeto missionário, os carmelitas não possuíam um passado de militância. Foi o contexto da expansão ultramarina que levou os carmelitas a repensarem seu modus vivendi, incorporando a missão como parte de suas atribuições. ${ }^{35}$

A expansão ultramarina alavancou a Companhia de Jesus, junto com seu ideal militante, à linha de frente da luta da Igreja Católica pela universalização do catolicismo. A chegada do europeu à América marcou o início de uma acirrada disputa no clero regular pelo protagonismo no estabelecimento de missões nos quatro cantos do orbe terrestre. Para sobreviverem a esse novo mundo que se expandia, as ordens religiosas buscaram participar ativamente desse processo de mundialização, tentando atender as demandas que cresciam à medida que a Igreja perdia espaço na Europa para a Reforma Protestante.

O século 16 é o século da reforma, da grande ruptura, do cisma, da túnica sem costura rasgada em duas. E tanto aqui como lá, são cristãos que se opõem, sem dúvida, mas cristãos que se excluem reciprocamente [da] cristandade. Desde então, essa velha noção de cristandade aplicada como unidade à totalidade das populações do Ocidente professando o cristianismo não é mais possível. A cristandade? Ela é rasgada. A do papa não é mais a de Lutero, a de Calvino não é mais a de Inácio de Loyola. Não se pode mais usar a mesma palavra, a palavra cristandade, para agrupar, para reunir homens que, precisamente no terreno cristão, se divorciam. ${ }^{36}$

Era necessário adequar a prática do clero regular às necessidades que surgiam nesse novo contexto; daí explica-se porque os carmelitas calçados adotaram o ideal militante de catequização do mundo.

Para as ordens religiosas na América portuguesa, o apostolado, transmutado no trabalho missionário, adquiria um novo status em virtude das milhares de almas que lá existiam.

A descoberta da América revelou-se depois como um verdadeiro traumatismo teológico. Seria possível que tantos homens fossem condenados? E os índios seriam realmente homens? Alguns duvidaram disso até ao momento em que Paulo III respondeu pela afirmativa na sua bula Sublimis Deus de $1537 .^{37}$

A bula estabelecia que os índios possuíam alma, sendo passíveis de catequização. A admissão de que esses índios possuíam alguma fé fazia parte da leitura que o missionário fazia do indígena. Como bem coloca Maria Cristina Pompa:

\footnotetext{
${ }^{35}$ Para se justificarem, os carmelitas recorreram à figura de São Bertoldo, um ex-cruzado que era tido como primeiro geral dos carmelitas quando a Ordem ressurgiu no final do século XI, e ao mito eliano de fundação da mesma, que colocava o profeta Elias como fundador direto do Carmelo, exaltando sua figura como personagem místico-militante. Sobre esse assunto, ver: André Cabral Honor, O verbo mais-que-perfeito: uma análise alegórica da cultura histórica carmelita na América portuguesa, Belo Horizonte, Fino Traço, 2013.

${ }^{36}$ Lucien Febvre, A Europa: gênese de uma civilização, Bauru, Edusc, 2004, p. 181.

${ }^{37}$ George Minois, História dos infernos, Tradução de Serafim Ferreira, Lisboa, Teorema, 1997, p. 300.
} 
A necessidade, filosófica, de atribuir aos índios crenças mesmo se vagas ou errôneas, obedecia a uma exigência cultural de "ler" o outro e traduzi-lo em seus próprios termos, e, por outro lado, traduzir o "eu" para o outro. Para isto era necessário construir uma linguagem de mediação. O código prioritário de leitura e interpretação da realidade, inclusive das alteridades antropológicas, ainda era, no início da Idade Moderna, o religioso; este último englobava todos os outros; o moral, o político, o filosófico (lembre-se a justaposição de fé, lei e rei). Ou seja, qualquer manifestação social da alteridade que a descoberta apresentava era lido sub specie religionis, e traduzido na linguagem religiosa. ${ }^{38}$

Converter essas pessoas era fulcral para a Igreja compensar a perda de fiéis para as reformas protestantes que cresciam na Europa. Os religiosos que saíssem na jornada de conversão dos infiéis estavam movidos não apenas pela "caridade para com o próximo", pois não salvariam apenas as almas dos povos indígenas, mas também a sua própria: "o fim da companhia não é somente ocupar-se, com a graça divina, da salvação e perfeição das almas próprias, mas, com esta mesma graça, esforçar-se imensamente por ajudar a salvação e perfeição do próximo". ${ }^{39}$

\section{Enquanto os jesuítas continham no cerne de suas competências um projeto missionário, os carmelitas não possuíam um passado de militância}

Base da catequese jesuítica, a redenção do espírito por meio da conversão do outro movia a ação militante e foi utilizada como diretriz de atuação de outras ordens na América portuguesa, dentre elas, os carmelitas.

Este expansionismo incorporava características inexistentes na experiência prévia dos cristãos e na visão agostiniana, ao transformar todos aqueles fora da jurisdição da Igreja e do papa em infiéis e inimigos a serem convertidos ou vencidos. A ideia de uma Guerra Santa não pertencia ao cristianismo primitivo, mas ao islamismo, justificada até mesmo por filósofos do porte de Alfarabi. O cristianismo dos primeiros séculos valorizava, significativamente, o martírio, a morte sem resistência em nome de Deus. A contundente afirmação da "cristandade" trouxe para a vida da Europa cristã o programa muçulmano, organizando as Cruzadas como vivência guerreira da fé e experiência carismática da morte, fatores tremendamente poderosos de unificação comunitária e afirmação da autoridade papal. Este espírito expansionista, intolerante e agressivo teve especial impacto na Ibéria, fronteira europeia que separava cristãos e muçulmanos. ${ }^{40}$

\footnotetext{
${ }^{38}$ Maria Cristina Pompa, Religião como tradução: missionários, Tupi e "Tapuia" no Brasil colonial. Tese de doutorado, Universidade Estadual de Campinas, Campinas, 2001, p. 35. Disponível em: <http://www. bibliotecadigital.unicamp.br/document/?code=vtls000220275>. Acesso em: 6 de setembro de 2014.

${ }^{39}$ Ignácio de Loyola, Constituições da Companhia de Jesus e normas complementares, São Paulo, Loyola, 2004, p. 46

${ }^{40}$ Rubem Barboza Filho, Tradição e artifício: Iberismo e Barroco na formação americana, Belo Horizonte, Editora da UFMG; Rio de Janeiro, IUPERJ, 2000, p. 163.
} 
O conceito de salvação da alma do missionário por meio da conversão do outro estava presente dentro da Ordem de Nossa Senhora do Carmo desde o início de seu projeto missionário na América portuguesa. Ao final da carta escrita por Frei João Cayado, o autor afirma que a vinda dos quatro religiosos carmelitas seria útil não apenas para a salvação das almas convertidas, como também os frades "alcançarão grande premio da caridade"; em outras palavras, por meio da conversão do "outro" salvar-se-ia o "eu".

Para a doutrina ibérica, católica e tridentina seiscentista, a vida era um sonho e o mundo um teatro, porque a verdade estava fora do mundo, em Deus. E assim, tudo era figura e imagem de Deus e efeito da Criação. Tudo era um sonho e teatro da Criação e do Criador. A Causa Primeira do Mundo, Deus Criador, também apontava para a Causa Final, Deus Julgador. A Criação, origem de tudo, na qual o humano fora feito com alma imortal, razão do livre-arbítrio, apontava necessariamente para o seu fim, o Julgamento Final, quando se separariam aqueles que condenaram a alma ao usar a razão e o livre-arbítrio para o erro, sucumbindo aos bens enganosos da carne, daqueles que se salvariam pois aplicaram suas escolhas, de modo racional e livre, no refreio dos desejos do corpo e no controle das paixões da alma. A História humana seria o caminho da Criação para o Julgamento Final. Deus dera à humanidade uma graça: completar o Seu projeto, o destino do mundo e da Criação por meio do livre-arbítrio. Aos humanos, tornados causas segundas da Criação, restava seguir esse desidério, orientando a vontade com bom entendimento e a memória das boas leis e bons exemplos, a fim de escolher entre os erros o acerto. ${ }^{41}$

Com base nas considerações anteriores, percebe-se o impacto que a criação da Companhia de Jesus teve sobre a cristandade, em especial, sobre o clero regular. A ideia de salvação dos jesuítas baseava-se na conversão do outro; somente por meio de cooptação de almas para o universo cristão, o frade da Companhia poderia salvar a si mesmo.

O fim expresso da Companhia é o de salvar a alma de seus membros, e a salvação da alma do próximo é o meio para atingir esse fim. Portanto, a missão que consiste em precisamente em obrar para a salvação da alma de seu próximo é apresentada como o meio para atingir aquele fim. De imediato existe uma ligação muito forte entre a salvação dos membros da Companhia e a do próximo; é a mesma "graça divina" que sustenta os dois projetos, atingir sua salvação e buscar a dos outros. O próximo é colocado como meio para atingir sua própria salvação. ${ }^{42}$

Essa concepção de salvação encaixava-se perfeitamente no contexto da expansão ultramarina, que revelou não apenas novas terras e um mundo circular, mas também milhares de pagãos que viviam alheios às palavras de Cristo.

"4luuís Filipe Lima; Ricardo Valle, "Introdução", In: Pedro Calderón de la Barca, A vida é sonho, Tradução de Renata Pallottini, São Paulo, Hedra, 2008, p. 16-17.

${ }^{42}$ Charlotte de Castelnau-L’Estoile, Operários de uma vinha estéril: os jesuítas e a conversão dos índios no Brasil: 1580-1620, Tradução de Ilka Stern Cohen, Bauru, Edusc, 2006, p. 95. 
No intuito de legitimar a posse dessas terras, Portugal e Espanha recorreram à Igreja, que reconheceu esses dois países como donos das novas terras, validando a conquista por meio de bulas papais. Como contrapartida, espanhóis e portugueses deveriam salvar esses pagãos, levando o catolicismo até eles. A recém-criada Companhia de Jesus assumia a dianteira nesse processo, com sua concepção militante de clero regular, ideia que foi quase concomitantemente copiada pelas demais ordens religiosas que se espalharam pelo além-mar.

\section{As diretrizes definidas na carta de Frei João Cayado moveram os carmelitas durante todo o período em que Portugal possuía parte da América}

Assim, ciente desses novos ventos que levavam a Igreja Católica até os quatro cantos do mundo, a Ordem de Nossa Senhora do Carmo aportava no Brasil com a missão de catequizar os indígenas e evangelizar as pessoas. As diretrizes definidas na carta de Frei João Cayado moveram os carmelitas durante todo o período em que Portugal possuía parte da América. Apesar de reinventarem sua prática em função dos desafios que lhes eram apresentados, as razões que justificavam a presença dos frades nos trópicos não sofreram maiores alterações durante mais de duzentos anos: estavam aqui para evangelizar as almas, com especial atenção aos indígenas. Em 1687, foi exigido das ordens religiosas que se ocupassem da catequização dos indígenas: "Carta régia de 15 de março de 1687, dirigida ao governador João da Cunha Souto Maior, mandando que notifica-se os prelados das ordens religiosas a se ocuparem na propagação da fé e conservação do gentio". ${ }^{43}$ Uma carta régia de 4 de março de 1743 manda expulsar as ordens religiosas que não estivessem catequizando os indígenas: "Declararão-se extinctas as ordens monasticas que se não applicassem a conversão do gentio, que era o fim primario de sua instituição, e transferidos os conventos aquellas que cumprissem de feito os seus deveres". ${ }^{44}$

Essa situação só iria se alterar na segunda metade do século XVIII, quando a política indigenista pombalina transformou gradualmente os aldeamentos em vilas. Os mesmos motivos que trouxeram os carmelitas para as terras do além-mar no século XVI também são parte dos motivos que explicam sua decadência a partir do final do século XVIII. A supressão da catequização dos indígenas, optando-se por uma administração laica, a predileção do clero secular em detrimento do regular na celebração dos rituais católicos, o aumento no número de dioceses e a desvinculação do Brasil a Portugal - todos esses motivos aliados a uma política romana de supressão das ordens religiosas tornaram a presença dos regulares na América quase obsoleta.

${ }^{43}$ Francisco Augusto Pereira da Costa, Anais pernambucanos, vol. 3, Recife, Arquivo Público Estadual, 1952, p. 110. ${ }^{44}$ João Manuel Pereira da Silva, História da fundação do império brasileiro, Tomo I, Paris, Garnier, 1864, p. 167. 
Após o duro golpe sofrido durante o reinado de D. José I (1750-1777), o clero regular conseguiu diminuir o ritmo desse processo de decadência durante o governo de D. Maria I (1777-1799), por se tratar de uma rainha extremamente devota, que custeava a construção e reformas das igrejas. Todavia, não houve renovação do papel a ser exercido pelos membros do clero regular na América portuguesa. Com a ascensão de D. João VI (1799-1826) ao trono português, prosseguiu-se com a política de supressão das ordens religiosas em Portugal e seus domínios. Sem conseguir reestruturar seus propósitos, os carmelitas esmaeceram até quase desaparecerem. Somente com a reinvenção do papel missionário no século XX, a Ordem Calçada de Nossa Senhora do Carmo voltou a prosperar, imbuída pela necessidade de restabelecer o elo que havia se rompido entre sociedade e clero regular. 